\title{
Towards an interdisciplinary ICT applied ethics: language matters
}

\section{Por uma ética aplicada interdisciplinar das TIC: matéria de linguagem}

\author{
Marcelo Buzato* \\ Universidade Estadual de Campinas \\ Campinas, São Paulo, Brasil
}

\begin{abstract}
This study seeks to support an interdisciplinary, theory-practice integrated work on the applied ethics of information and communication technologies (ICT). Current work on applied ICT ethics is of a disciplinary nature and seeks to apply traditional philosophical norms to novel situations that are not easily identified by analogy to previous cases. I propose an alternative view in which ICTs are seen as a moral environment and ethical agents are seen as human-computer hybrids (cyborgs) whose experiences acquire ethical value ecologically. To implement such a view, I propose employing two different kinds of semiotics: a semiotics of meaning-making that is open to the environmental effects of cyborg acts across scales, and a material semiotics that allows for interdisciplinary practitioners to recognize the modes of existence involved in the ethical issues and work out better means-ends relationships among the modes pertinent to each discipline.
\end{abstract}

Keywords: ICTs; applied ethics; applied linguistics; post-humanism, meaning-making.

Resumo: Esta pesquisa busca apoiar um trabalho interdisciplinar que integre teoria e prática acerca de uma ética aplicada das tecnologias digitais da informação e comunicação. O trabalho atual em ética aplicada das TIC é de natureza disciplinar e busca aplicar normas filosóficas tradicionais às novas situações as quais não são facilmente identificadas por analogia a casos anteriores. Eu proponho uma visão alternativa pela qual as TIC são vistas como um ambiente ético e os agentes éticos são vistos como híbridos humanocomputador (ciborgues) cujas experiências adquirem valor ético ecologicamente. Para implementar esta visão, proponho que se empregue dois tipos distintos de semiótica: uma semiótica da significação que esteja aberta aos efeitos ambientais das atividades dos ciborgues em diferentes escalas, e uma semiótica material que permita aos praticantes de diferentes disciplinas reconhecerem os modos de existência envolvidos nas questôes éticas e buscarem melhores relaçóes do tipo meio-fim entre os modos implicados por cada disciplina.

Palavras-chave: TIC; ética aplicada; linguística aplicada; pós-humanismo; significação.

$\overline{\text { *marcelo.buzato@gmail.com }}$ 


\section{A prologue on ambiguity and incompleteness}

This paper presents the initial results of a research project aimed at achieving a metadiscursive/metatheoretical reasoning framework for an applied ethics of ICTs viewed as postsocial/post-human ethics of the here and now. These are philosophical and analytical-methodological perspectives that have a longstanding tradition, however short, in the digital humanities and social sciences, which most readers are probably already aware of to some degree. While pointing the readers to the works of Katherine Hayles (1999, 2011) and Karen Knorr-Cetina (1997, 2001, 2005) for a panoramic introduction to those traditions, I would like these terms, as used here, to refer to the definitions that follow.

"Postsocial" is a sociological perspective that emphasizes object relations as well as subject relations in explanations of social behavior. It recognizes that epistemic objects (especially computers and computerlike devices) are increasingly replacing human peers as both social context and/or activity partners in everyday life. This has become possible because computers, as all epistemic objects, unfold in reciprocity with human desires and needs.

"Posthuman" refers to a critical, deconstructivist account of the illuminist notion of human nature and the liberal conceptualization of the social subject. As a body of heterogeneous literary, philosophical, and technoscientific discourse, posthumanism challenges our received notions of body, intelligence, mind, soul, subjectivity, and consciousness by emphasizing human co-evolution with artifacts, the human physical, cognitive, and affective co-dependence on prostheses, media, and other biological species. There are politically benign and malign versions of posthumanist critique, imagination, and techno-scientific entrepreneurship, some of which are deemed anti-human and others transhuman, i.e., wishing to eliminate all human predicaments through technology so that humans manage their evolutionary trajectory in order to become immortal.

Pursuing a metatheoretical/metadiscursive framework for an applied ethics of the ICTs viewed as postsocial/posthuman ethics of the here and now is obviously a monumental task that I by no means intend to suggest can be handled by one researcher in one paper. Yet, like many colleagues in other fields, I would like to propose this necessary and urgent discussion to my own community, so that it finds some possible points of intersection with other fields in a holistic, organic, distributed, and networked endeavor of this kind. 
Obviously, this kind of endeavor is poorly served by monomodality, print technology, and traditional academic genres. Therefore, this paper is flagrantly overreaching, if not politically naïve, since it deals with vast and complex literature, of which the depth cannot be fairly accounted for in only a few pages. In particular, I will draw upon the work of two specific authors, Bruno Latour and Jay Lemke, whose oeuvres are fairly well known by Brazilian applied linguists, but are also too complex and far-ranging to be summarized in one section of one academic paper. I will, thus, depend on the generosity of the readers to tolerate a certain vagueness in my proposal, and their willingness to follow my pointers to pertinent introductory literature, if necessary. On the other hand, I will also depend on the indulgence of readers from academic fields other than applied linguistics that are implicated in my argument to forgive the shallowness with which I had to introduce concepts and ideas from those fields here.

In sum, I wish this paper to be thought of as overreaching but not pretentious, far-fetched but not romantic, and as an invitation to learn together about what we are becoming, hopefully with colleagues from many other fields. Should this message in a bottle meet a like-minded readership, I am sure a next step would be to develop more flexible, multimodal, crossmedia forms of discursive activity, as well as instruments of evaluation and scientific accountability. Above all, we must find different ways to bring ordinary people and ordinary language into these discussions, given that it is in the lived trajectories of everyday lives that the ethical dimension of a global human-computer ecology becomes politically relevant.

In the first section, I present an anecdote about an interdisciplinary project aimed at improving e-government interfaces with the purpose of illustrating the need for a new kind of interdisciplinary endeavor which embraces ethical work involving ICTs. I propose that, upon creating new mediations to help adapt users to the ways things work in ICTs, we are in fact creating cyborgs and are therefore dealing with a posthuman ethics of the here and now. It is my belief that we need to develop an appropriate metadiscursive/metatheoretical framework to accomplish this goal.

In trying to approach this discussion to applied linguistics, I dedicate the second section to review the basics of moral philosophy and metaethics, the latter being understood as an attempt to extract a language of morals from moral language. I defend that an applied ICT ethics based on this strategy is ineffective, as one cannot merely pre-load the ethical value of 
human-computer experiential trajectories from logical relations and must instead rely on the experiential trajectory of cyborg agents.

In the third section, I present a state-of-the-art of the current discussions in applied ICT ethics led by professionals of the computer and information sciences. I show that the mainstream in these discussions recurs within a great variety of ethical theories and metaethical positions in the face of uncertainties caused by the integration of computers within a wide range of social practices. However, an alternative view begins to gain importance in the field which advocates a phenomenological approach by which the ethical value of the act is disclosed in an archeology of the human and non-human agencies involved.

In the fourth section, I propose that two theories could be brought together in order to support a kind of ethical reasoning concerning the new ethical issues that become apparent when we view ICTs as an ethical environment and consider the ethical meaning of acts as constructed in the cyborgian experience. I suggest Jay Lemke`s ecosocial semiotics could be used to study the real-life, environmental effects of the material-semiotic processes carried out by cyborg agents in different scales. Moreover, Bruno Latour's material semiotics can be used as a reflexive device for interdisciplinary teams to become aware of the ethical implications of translating entities into different modes of existence and to figure out ways to protect these ethical dimensions in the users' thread of experience.

In the final section I pose some ethical questions that this approach might help generate in relation to the anecdote offered in section one as an illustration of the kind of reasoning and research that could possibly be derived from the overall argument.

\section{Introduction: from why to how language matters}

"Why does language matter here?" is what an applied linguist often asks when trying to engage with a new research object. But when "here" is the ethical environment comprised of current human-computer activity, defined herein as ICTs, I argue "how does language matter?" is a question we also must ask. I will use the verb "to matter" in both its figurative and literal senses in this paper, even though a literal sense of "to matter" is not in the dictionary. I do so because, in the living trajectory of this language, nouns can sometimes also be verbs. Hence, the reader's languaging (SWAIN, 1985) mind may not mind such ambiguity. 
As a matter of fact, ambiguity is a central notion in this work, as is the notion of an ethical environment. Blackburn (2002, p. 1) defines an ethical environment as:

the surrounding climate of ideas about how to live [which] determines what we find acceptable or unacceptable, admirable or contemptible [...] our conception of when things are going well and when they are going badly [and] our conception of what is due to us, and what is due from us as we relate to others.

The ambiguity I refer to here becomes apparent when we understand that ICTs are not only an infrastructure that is physically contained in the same material substrate where sentient beings act and are acted upon, but they are also a series of dynamic material-semiotic processes that affect our perception and understanding of what is "out there" beyond our physical presence. Therefore, just as speakers pursuing meaning engage in languaging (THIBAULT, 2011), networked computers-plus-users engage in "mattering"; they materialize something in the world.

In other words, as we use ICTs to translate what some of us believe is an essentially computational world into signs, we engage in material relations that affect the sensitive world in ways that require new readings, and those, in turn, may well be further translated through computations, and so on and so forth. In other words, in pursuing a definition of what is, humans and computers together are also defining what ought to be and vice-versa. Let me illustrate with an anecdote.

About a decade ago I participated in the initial phase of a supposedly interdisciplinary research project on e-government interfaces. I say "supposedly", because it worked more like a hierarchical multidisciplinary job in which the applied linguists, the language people in the project, were assigned a task previously defined by the engineers and system analysts, the computer people: to rewrite the contents of certain e-government interfaces using a lexicon and a phraseology that "everyone would understand."

The design philosophy that guided the project was Universal Design (henceforth UD) (Story et al., 1998). UD started as an epistemic response to the disability rights movement (Shaw, 2008) in the US. Out of a politics of access, it turned universality into a moral value. Providing concrete means of achievement towards universality is the UD practitioner's ethical task. But one might want to ask: is universality a means or an end? 
In the case at hand, the computer people modeled functionally illiterate users in cognitive ergonometric terms, which rendered them "disabled", as measured through their performance of a given task in much the same sense as vision, motion, or hearing impaired users are measured, as odd as it may seem. This "mattering" of the illiterate struck a very dissonant note with the language people, of course, especially because they leaned towards the ideological model of literacy (STREET, 1984) rather than the radically functional approach implicit in the computer people's rhetoric. This, in turn, led the language people to present a plethora of academic evidence to support their vision of what language and literacy are all about, which was followed by a rejoinder from the computer people about the need for a single norm for any communication process to be efficient, and, eventually, to silence on both sides until a political commitment could be made.

Basically, in order to bridge the epistemic-ontological gap between these views and materialize something that both groups could accept, the language people decided to invite colleagues who specialized in corpus linguistics to join the discussion, and those colleagues managed to extract the most frequent (rather than simplest) lexical items and phrases from a database of oral histories recorded by real people whose biographical records matched the ontological requirements of an average agreed upon persona, a vector comprised of logical/ numerical properties rather than any embodied citizen in particular.

In attempting an interdisciplinary applied ethics of utilitarian nature, the team configured an ingenuous ethical mediation: the language people would facilitate the interface (the end) to help the computer people make effective users (the means); the computer people would make the state bureaucracy more effective (the end) by facilitating the citizens to be (the means). Together, they were planning to release cyborg citizens ${ }^{1}$ (GRAY,

\footnotetext{
${ }^{1}$ I use the term cyborg in this essay in accordance with Gray's (2000, p.2) definition, i.e., "a cyborg is a self-regulating organism that combines the natural and artificial together in one system. Cyborgs do not have to be part human, for any organism/system that mixes the evolved and the made, the living and the inanimate, is technically a cyborg." Likewise, I borrow the notion of cyborg citizen from Gray (2000, p. 20-32) for whom a cyborg citizen is an embodied being (whether such body is organism, machine, or both) who can competently participate in the Polis as a discourse community. I realize, and so does Gray, that this conceptualization is problematic and requires further discussion and investigation, but it suffices for my purposes here as long as my reader, like Gray's, agrees to treat it as a "working idea", not a universal, naturalized concept.
} 
2000) in the world.

As Latour (1994) has famously argued in relation to the traditional debate about gun control in the US, when a cyborg, such as a human-plusfire-arm, acts ethically, either as a slayer or as a law enforcer, neither the artifact nor the human user can be taken, by itself, as the ethical agent. The agent is a third being created by the association of human and artefactual agencies. The ethical agency is hardly predictable if either agency is considered alone. Each agency passes through the other in order to sustain itself and, in doing so, somehow is deviated. That is how cold-blooded murder, manslaughter, or self-defense killing come into the world, three very distinct kinds of ethical worth for the exact same formal-actional coupling.

As more and more human-computer cyborg agencies make ambiguous meanings in lived trajectories in the sensitive world, new ethical issues become available to which previous moral norms apply inefficiently (MOORE, 2004). To claim that we are improving this new ethical environment, we must work towards a new politics of sentience; we need to study the new ways in which we can hurt or be hurt by the other, as well as what is due to and from us as cyborg citizens on a planetary scale.

Computers, like fire arms, have no feelings and no intentionality, and they do not define their goals in the sensitive world. But they can internally generate what will later become ethical decisions, through translations between moral trust and epistemic trust (BUECHNER, 2013), since both are amenable to normativity. In other words, because computers are normative machines that rule over what can exist for themselves, they often become ethical agents who rule over what humans and non-human agents must or must not do through them. In doing so, computers become part of the Polis, and their internal politics must conform to that of the citizens.

This is what makes human-computer cyborg ethical agencies so hard to grasp politically: they are doubly ambiguous agents: not only do they transport agency about, but they also act in disputed aboutness. Human constructors, users, and cybernetic machines (including software) acting together as cyborgs will inevitably experience the Polis and act ethically in partial transparency and partial withdrawal (IHDE, 2011). My GPS application might help me take someone to the hospital faster by showing me a short-cut I did not know existed, but the short-cut can be a crimeridden alley where I am going to get caught in a shootout. The constructor may include the information about shoot-outs and crime rates in the GPS 
application, but that would probably jeopardize the chances of honest people living in the area getting a job because of their ZIP code. For every way in which computerized systems augment human awareness and sensitivity, some part of their sentience and sensibility is also affected by the computers' inability to be truly aware of human pain or pleasure.

Therefore, the main argument I wish to put forward here is that if researchers from the humanities and the so-called hard sciences and engineering wish to engage democratically and effectively with an applied ICT ethics, they will need to work together on a new kind of interdisciplinary reflexive metatheoretical and metadiscursive framework that embraces the ambiguities of being-doing and meaning-feeling. A good starting point, I suggest, would be to view moral philosophy and metaethics more precisely in order to find out what they can and cannot offer in this case.

\section{Moral philosophy, metaethics, and the bridging of the is-ou- ght to gap}

Moral philosophy is concerned with how we ought to act in order to live a good, happy life. Metaethics discusses the limits and properties of moral philosophical theories and of morality itself. Applied ethics seeks the best ways to apply ethics theories to professional practices or domains of human activity. Its product is a renewable body of policies and good practices. Together, these three inter-related fields have more to do with language than is often noticed by applied linguists. I will limit myself to the four main ethics theories: virtue ethics, intentionalism, normativism (deontology), and consequentialism (utilitarianism). Next, I will make a brief incursion in metaethics.

For Aristotle, ethics guides humans to the source of their well-being (eudaimonia), which is, ultimately, living in accordance with their own pre-assigned nature. To achieve this, one needs access to material resources of certain kinds, which depends on chance, and needs to develop virtue, emotional reactions, choices, values, desires, perceptions, attitudes, interests, expectations, and sensibilities, which can be cultivated (KRAUT, 2014) and turn into "a disposition which is well entrenched in its possessor" (HURSTHOUSE, 2013, Item 2). Reason alone will not suffice to define the ethical worth of one's acts, in this case, owing to the fact that the material conditions one faces are always uncertain. The ethical act requires phronesis, i.e. the "sensitivity, perception, imagination, and judgment 
informed by experience [...] needed to apply rules or principles correctly" (HURSTHOUSE, 2013, Item 3).

Intentionalism (KING, 1995), a second landmark, starts with the Augustinian concept of sin by intention and gains momentum with Peter Abelard (1079 - 1142), who argued that all humans bare both good and evil traits or dispositions; hence, it is the intention behind one's act that defines one's moral worth. The dismissal by the sarcastic Christian aphorism "the road to hell is paved with good intentions" notwithstanding, intentionalism emphasizes the epistemic status of the agent as a definer of her moral agency.

Deontological ethics (ALEXANDER; MOORE, 2015), best represented by Kantian moral philosophy, deems actions good or evil by reference to norms that appeal to human reason through a logic of means and ends. Certain means can be deemed unequivocally good, and thus become ends in themselves or categorical imperatives. The ethical worth of any new act can be determined through an analogy to a previous situation according to such imperatives or universal prescriptions. The ultimate source of Kantian categorical imperatives is metaphysical, or God, and need not be proven, as God is goodness by definition.

Utilitarianism (consequentialism), the theory of choice in the modern liberal West and for most computer applied ethicists, argues that categorical imperatives conflict among themselves in practice when one takes the concrete consequences of actions into account. It is pleasure/happiness (good) and pain/fear (evil) as consequences (ends) that should describe the moral worth of an action (means). Here, the epistemic component that Abelard attached to agency is transferred to causality, so that goodness and evil can be safely arrived at by calculation: "It is the greatest happiness of the greatest number that is the measure of right and wrong" (Bentham, 1988, p.393).

As can be seen, if virtue and intention are taken out of the picture, as is the case in objective reasoning that befits computer matters, the main line of tension is that between those who defend a normative/prescriptive foundation for ethics and those who defend an epistemic/descriptive one.

This split goes back to David Hume's (1639, p. 335, my emphasis) famous is-ought to problem, which he first described in these words:

In every system of morality, which I have hitherto met with [...] the author proceeds for some time in the ordinary ways of reasoning, and establishes the being of a God, or makes observations concerning human affairs; when all of a sudden I am surprised to find, that instead 
of the usual copulations of propositions, 'is', and 'is not', I meet with no proposition that is not connected with an 'ought', or an 'ought not'. This change is imperceptible; but is however, of the last consequence. For as this ought, or ought not, expresses some new relation or affirmation (...).

Hume's guillotine can be understood primarily as part of the author's more general critique of causation, in this case, denouncing a lack of causation between what is (metaphysics) and what ought to be (ethics), which would later become an argument against religious and deontological morality. However, as Brandt (1963) points out, Hume's exercise of seeking relations between moral language and languages of morals (ethical theories) is at the heart of metaethics as a whole. It is virtually impossible to do justice to the whole of metaethics here, so I must limit myself to the most essential elements to defend my argument, and use Figure 1, along with the bibliographical pointers in its caption, to help the reader gain a more overall perspective.

Brandt's (1963) emphasis on moral language helps us understand why metaethics has so many divergent positions: we can express obligation in natural language in many ways, some of which are explicitly normative (e.g., imperative moods and modal verbs), while others are not (e.g., illocutionary acts and figurative language). Apart from that, if ethics is a matter of fact, we should be able to talk about moral statements in terms of truth-apt propositions (cognitivism). To know if a belief is true or false, we have the analytic manner - making logical deductions and inferences - which requires no reference to lived experience or the synthetic manner - using reference to something else that can be experienced in the world. In either way, a tradeoff is implied: we can avoid Hume's guillotine, but only if we cut all paradigms other than that comprised of logical propositions out of the language.

If we maintain that moral statements are a matter of categorical imperatives, we will need to go through the guillotine somehow to establish the adherence of future or past facts to the pre-given norm. But both imperative moods and illocutionary attachments (Searle, 1969) complicate attempts to derive new prescriptions from previous ones logically, since the statements that belong to those paradigms are not truth-apt and have no explicit intentional operators that would allow them to drop properties (MATURANO, 2015). One can push the cognitivism envelope and start from the propositional content implicit in imperative statements to perform logical inferences, but those will lead to logical imperatives that will most often lead to paradoxes and puzzles (HANSEN, 2008). One can, 
alternatively, consider moral prescriptions a matter of attitude or feeling rather than fact (Subjectivism), or even as part of a social contract or even a matter of persuasion (non-naturalism), in which case the moral properties are not to be found in moral language itself.

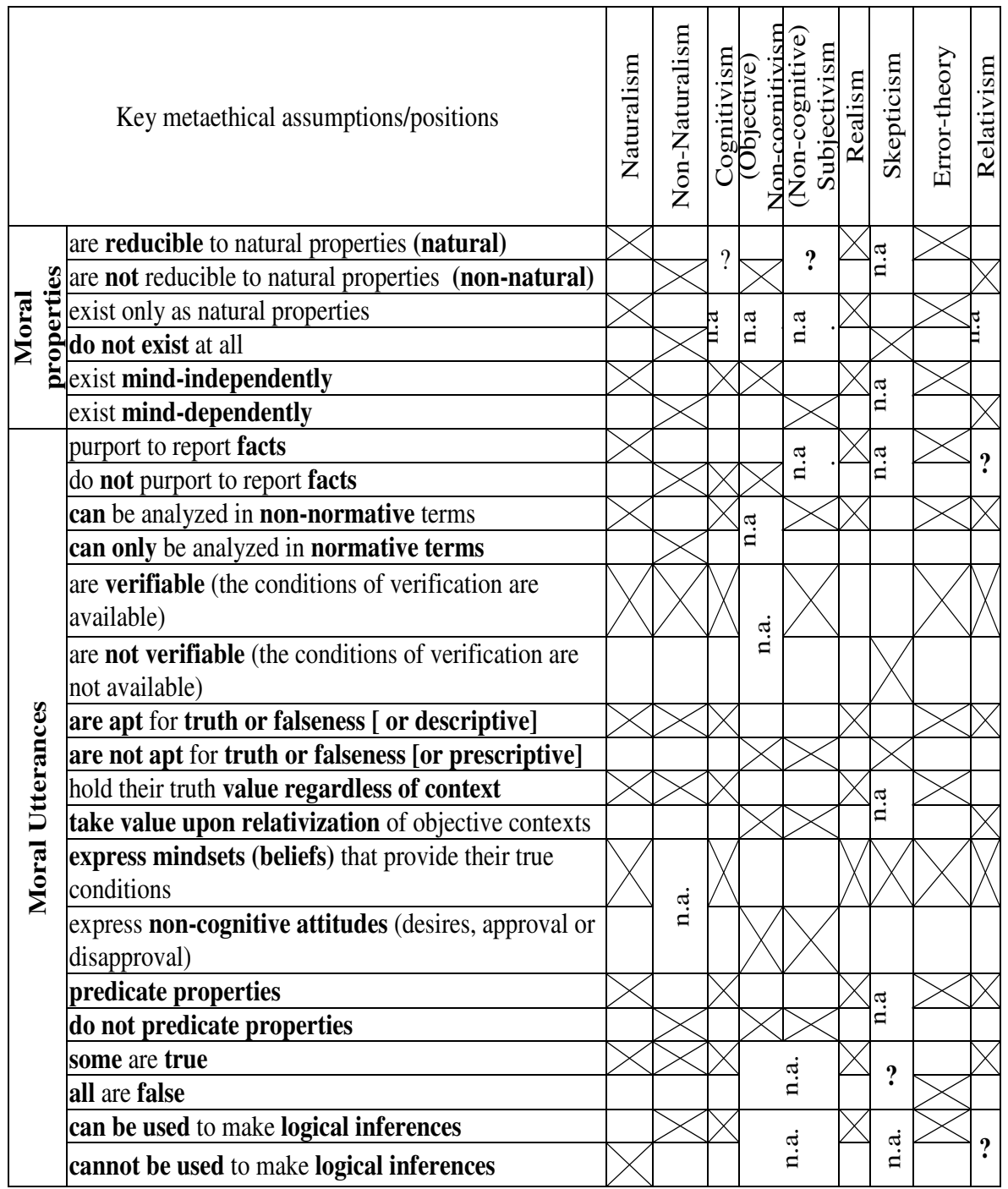

Figure 1: Key metaethical stances and assumptions (HANSEN, 2008; JOYCE, 2015; LENMAN, 2014; RIDGE, 2014; VAN ROOJEN, 2015) 
If we believe, like most cyberneticists, that the world is fundamentally computational (HAYLES, 2006), in which case logical-mathematical signs and relations "transport" (ethical) properties of things, we may very well feel able to pre-load computers with ethical information. But if we take the ethical agent to be a human-computer hybrid, we need to accept that the ethical act will also consistently have at least the possibility of a non-epistemic component, be it non-cognitive, non-natural, skeptic, or subjective. Hence, either human or computer withdrawal will have an effect in the sensitive world. If meaning and feeling are essentially part of the same (often ambiguous) material-semiotic process (LEMKE, 2015), could humans coevolve with computers by unlearning to make non-cognitive, non-naturalist moral meaning? Or should we develop computers that learn to read and process human feelings more accurately and take those into consideration in their translations of ethical trust into epistemic trust? How can so many mistranslations go unpunished in a society that deems itself democratic if not because of the illusion that computers have no morals and no politics?

Just as Hume noticed an imperceptible change from "is" to "ought to be" in the languaging of the moral philosophers of his time, we are now facing a practically imperceptible change from the deontic/directive to the probabilistic/veridictive function of the modal operators based on which computers work. Put more bluntly, for computers, either things happen as they ought to in a probabilistic sense or not; they are "fractures in the fabric of being" (FLORIDI, 2009, p.17) that simply do not matter. But at a time when computers are replacing human peers in so many societal routines and encounters (KNORR-CETINA, 2001, 2005), the effects of such a clever use of modal ambiguity in the sensitive word are probably just as devastating ethically as global warming is physically!

If we wish to begin to understand these new ethical environmental processes, entities, and phenomena, and act on them politically, we must, somehow, find a better way to deal with cyborg meaning-making ambiguities than to hide the authoritarian politics of machines under the modality carpet. We must do it, if not for other reasons, because such repressed ambiguity will resurface in our ordinary language when we talk about the new ethical issues that humans and computers create together.

\section{Applied ICT ethics, ambiguity, and alternative approaches}

The official field of applied ICT ethics goes by many names: "computer ethics" (henceforth CE), "information ethics" (henceforth IE), "computer 
and information ethics" (henceforth CIE), and "information and computer ethics" (henceforth ICE). Bynun $(2005,2014)$ attributes the nomenclature game to the epistemic impact of Wiener's (1954) classic "The human use of human beings: cybernetics and society." While IE is basically concerned with the management of information, cybernetics, the field founded by Wiener, is about information relations in teleological dynamic systems, of which computers are just one example. CE is, therefore, "a subfield of Wiener's much broader concerns" (BYNUN, 2014, Item 1).

Wiener (1954) realized that, in describing how dynamical systems in equilibrium work, cybernetics provided a certain vision of what a human society ought to be. Bridging the is-ought to gap in his own teleological, Liberal, post-war, hard-science laden mindset, he believed machines should be "used for the benefit of man, for increasing his leisure and enriching his spiritual life, rather than merely for profits and the worship of the machine as a new brazen calf" (WIENER, 1954, p.162). Clearly, Wiener realized that normative machines had a utilitarian ethical potential; however, he approached "cybernethics" (please forgive my pun) from a deontological point of view in which law, defined as "ethical control applied to communication" (p. 105), should rule human ethical behavior.

Like the computer people in my anecdote, Wiener (1954, p. 105) saw language as the transmission of semantic information. Where language people usually see the very stuff of society, i.e. discourse and its dynamics (LEMKE, 1995), cybernetics sees an impairment to semantic reception. Like a missile that needs to reassess the position of its target, for Wiener, a citizen needs to "assess his rights and duties in advance" in order to "lead a life free from litigation and confusion" (WIENER, 1954, p. 105).

Provided that clear language is used, Wiener (1954, p. 105-106) predicted the (ethical) environmental impacts of automation in society could be controlled by four "great principles of justice": Freedom - "the liberty of each human being to develop in his freedom the full measure of the human possibilities embodied in him," Equality - "what is just for A and B remains just when the positions of A and B are interchanged," Benevolence - "a good will between man and man that knows no limits short of those of humanity itself," and Minimum Infringement of Freedom - "What compulsion the very existence of the community and the state may demand must be exercised in such a way as to produce no unnecessary infringement of freedom."

As fair as it is to recognize that Wiener could not have predicted the current environmental consequences of the cybernetic revolution on a 
planetary level, to take ethical problems as already known and suitable to the pre-existing spirit of the law is an act of faith, more than reason, which provides the background to what is now known as the "uniqueness debate" in CIE (Bynun, 2014): after all, do computers create new ethical problems or do they merely introduce "new instances" of the same old problems?

Manner (1980, n.p., my emphasis) suggested the need for an applied ethics to study the problems "aggravated, transformed or created by computer technology”. Johnson (1985, p. 1, my emphasis) replied that computers "pose new versions of standard moral problems [...] forcing us to apply ordinary moral norms in uncharted realms". Manner's (1996, p. 152, my emphasis) rejoinder was that "when we confront unfamiliar ethical problems, $[\ldots]$ we try to transfer moral intuitions across the bridge $[\ldots]$ [but the] lack of an effective analogy forces us to discover new moral values". Johnson (2006) added the additional problem of defining the computer as an ethical entity or an ethical agent. For her, to consider computers as moral agents is to let their builders/designers/users off the hook.

Moor (2004, p. 26, emphasis) avoids the uniqueness debate by referring to ethical "impacts" rather than ethical "problems", thus reframing the problem of moral agency in terms of distributed human-plus-machine activity: computers are "logically malleable" machines; "logic applies everywhere " (Moor, 2004,p.23); therefore, as enablers of moral actions (MOOR, 1985, p. 266 as cited in SPINELLO; TAVANI, 2004, p. 18, my emphasis) computers "provide us with new capabilities" that "give us new choices for action" so that the limits of computers are "largely the limits of our own creativity".

To whom do the deictic "us" and "our" refer in these quotations is an important question that Moor leaves open, though. In their co-evolutionary spiral with artifacts, are humans free to act as they please? Do they only gain capabilities or do they also lose skills they used to have? If all possibilities are a function of human creativity, why do only some reap the financial profits? It is very tempting to include ourselves (me and the reader as computer users) in the space opened by "logical flexibility" provided by the Moor's ambiguous pronouns. But does everyone really believe that logic applies everywhere? Is anybody free to opt-out before the prophecy self-fulfills?

Technically, Moor (2004) describes the major impact of large-scale human-computer activity as "information enrichment": elements of social practice "come to be conceived as an elaborate computable function among people" (MOOR, 2004, p. 23, my emphasis). Just as the passive construction 
in Moor's explanation hides a semantic role behind a preposition indicating a vague spatial relation, CIE finds itself surrounded by "policy vacuums" (p.23) to fill and "conceptual muddles" (p.23) it cannot situate. Perhaps to Wiener's distaste, computers are proving that human laws are inevitably situated and languaged. How, then, to conflate heterogeneity and control, if not through a net of relations among self-contained objects or ruling systems? In this case Moor knits a net of distributed metaethical stances: an "accommodation between reasoned argument and relativity of values is possible" (moral relativism) through "rational consideration" (p. 30) (cognitivism) of "our fundamental values, based on our common human nature" (deontology): "life and happiness" is the end, "ability, freedom, knowledge, resources" the means (p. 23) (utilitarianism). Sometimes all it takes is "empirical adjudication" (naturalism), because "disagreements which might appear to be about values" (non-cognitivism) "are sometimes merely disagreements about facts” (p. 31) (realism). If it's not a matter of fact, nor of values, it's a matter of chance which can be solved with an elegant theorem (GRANT et al., 2010, p. 36): to "assume an impartial position when evaluating policy." Not a bad bricolage at all for computer people. But then there are also the information people to deal with, now.

Information Philosophy, a field led by Luciano Floridi (2002), reclaims territory from IE that Bynum (2014) says is Wiener's (1954). This possibly explains why Bynun (2014) writes of Floridi's ICE as FIE (Floridi's Information Ethics) and not ICE, while Floridi writes of CE as ICE. According to Wiener, it should be acceptable as long as what is just for $A$ and $B$ is just for $B$ and $A$. But is it?

Floridi (2008) addresses the problem of ICE from an ecological perspective, namely by pointing out the environment "in which humanity is and will be flourishing" (FLORIDI, 2008, p.3, my emphasis), the "infosphere" or:

the whole informational environment constituted by all informational entities (thus including informational agents as well), their properties, interactions, processes and mutual relations. It is an environment comparable to, but different from, cyberspace (which is only one of its sub-regions, as it were), since it also includes offline and analogue spaces of information.

This concept comes in the context of Floridi's (2008) critique of the "external model" of mainstream IE (information as resource, product, or 
target), and, as my emphases suggest, brings it all together into one single level of abstraction, where we could speak of region and space, agent and property, interaction and relation outside the empirical constraints of material-semiotic processes, hardware, and regional dialects. He qualifies this strategy as "ontocentric", and justifies it on the grounds that "there is something even more elemental than life, namely being (...) and something more fundamental than suffering, namely entropy" (FLORIDI, 2008, p. 12).

By appealing to the organization of what is as the most fundamental value to be considered and calling for a sentience-free environmental ethics, Floridi is clearly oversimplifying the real problem, which possibly explains why Bynum (2014) isolates his work in an idiosyncratic acronym. However, the notion of infosphere as an ethical environment does seem more attuned to what computer-human activity has come to mean today than did Wiener's belief in the realm of human-only law. Thus, the ontology baby needs not be thrown away with FIE's bathwater. What we need is a better approach to being, an ontocentric approach that is grounded on the thread of experience, like Latour's (2013), as I will explain in the next section. For now, let's look at Introna's phenomenological CIE, a second, more politically benign nonmainstream approach to ICE/CIE.

Inspired by Heidegger's (1971, p.181, as cited in Introna, 2003, p.7) famous claim that the thing "things" world, and in the general Heideggerian (1962) notion that technology discloses the human being-in-the-world (or dasein), Introna (2014) proposes an applied ICT ethics as a progressive "ontological disclosure" of the human trajectory of being-with-technology. His conceptual framework borrows from Actor-Network Theory (LATOUR, 1996) the notion that moral agents are constituted in unfolding relations of agencies. From Barad (2003), he brings in the concepts of intra-action, i.e., all phenomena are constituted by "dynamic topological reconfigurations/ entanglements/relationalities/ (re)articulations", and agential cut, i.e., the observer gives boundaries to a phenomenon by observing/measuring it with an "apparatus" (BARAD, 2003, p. 815). Thus supported, Introna (2014) suggests that we must create new discourses and new identities that legitimate the ways we intra-act common human values, but that we also need to "ask about the constitutive conditions that enable and constrain the emergence of those particular agencies as legitimate in the first place” (p. 50).

This kind of phenomenological approach seems, by far, more attuned to a democratic, interdisciplinary applied ICT ethics. However, the 
specifications of the intra-actions that generate ethical meanings, along with the acceptance of ambiguity as an intrinsic characteristic of cyborg ethics, demand that we develop a special kind of apparatus that allows us to disclose our own disciplinary ontological limitations reflexively together with the material-semiotic deeds that constitute our becoming ourselves over time. In short, we need to make agential cuts using an optical apparatus, instead of a cutting instrument like Hume's guillotine. The apparatus I am proposing is akin to that used in a double-slit experiment. We want together to see an object, but also to become aware of patterns of interference that make us see different objects in the same entity, process, or thread of experience. In other words, we want to observe the action of beings from different modes of existence (LATOUR, 2013).

\section{An ambi-optic apparatus to disclose cyborg ethical ambiguity}

The ambi-optic apparatus I propose is based on the question, "how language matters", and is comprised of two different kinds of semiotics: one to look at reference itself, the material processes of (ethical) meaning-making, from an ecological perspective, namely ecosocial semiotics (henceforth ES); the other to look at how technical mediations and disciplinary discourses create (ethical) agents and alter matters, namely material semiotics ${ }^{2}$ (henceforth MS). Both are anti-Cartesian approaches that have the advantages of having been constituted interdisciplinary themselves, and of aiming to bridge the sign-thing gap with work, rather than magic. Although they are complementary in certain ways (LEMKE, 2002), ES and MS stem from radically different ontological stances: relational wholism (MCGRAIL, 2008) for the latter and dynamical materialism (BUNGE, 1973) for the former. Therefore, the usefulness of bringing them together is not to produce unified explanations, but to create an ambi-optic instrument that will force the analyst to behold herself in the act of beholding the phenomenon and the other.

\footnotetext{
${ }^{2}$ I use the term "material semiotics" inspired by Law (2006), to encompass Latour's Actor-Network Theory (ANT) (LATOUR, 1996) and later developments of the same approach, especially, Latour's Inquiry into Modes of Existence (AIME) (LATOUR, 2013).
} 
In a nutshell, ecosocial semiotics brings dynamic complex systems theory ${ }^{3}$ as applied to evolutionary biology (SALTHE, 2009) to explain the dynamics of ecological environments that include human societies/ communities. Sometimes associated with the field of urban studies, it has successfully been combined with social semiotics (Halliday, 1978; Van Leeuwen, 2005) in Jay Lemke's research into ecosocial dynamics (LEMKE, 1995; 2000) and in Lemke's further works regarding learning, identity, literacy, and multimedia and transmedia communication (LEMKE, 2001, 2002a, 2002b, 2003, 2009).

In contrast with cybernetics, in ES, the system is not considered teleological, and moral considerability is not detached from sentience, as feeling and meaning are considered part of the same material-semiotic processes (LEMKE, 2015) that happen across scales (from the intra to the extracorporeal). ES can accommodate the notion of a cyborg as an ethical agent, since it views all entities in a system as epiphenomena of the pertinent dynamic processes. Inasmuch as human-computer peers bring together machine and human systems of interpretance (LEMKE, 2000, 2015) through recurrent patterns of activity, their meaning-making activity can be grasped together through the choice of appropriate cogent moments.

ES shares with MS the notion that relations and interactional linkages among heterogeneous elements established as material and semiotic processes constitute, develop, and change moral acts and moral agencies. Only, whereas MS gives us a philosophical account of material reality, ES provides a material account of meanings and interactions in a variety levels of reality (SALTHE, 2009). Therefore, the possibility of a broader explicit dialog between ES and MS is latent and, as a matter of fact, explicit in Lemke's mentions of ANT in his own work (LEMKE 1995, 2001, 2002b, 2015). I particularly think that establishing methodological connections between Lemke's (2015) unitary bio-semiotic account of feeling and meaning and Latour's (2013) emphasis on recovering experience in the multiverse could be immensely useful in an investigation of sentience, sense, and sensitivity in human-computer ecologies. Enter MS.

I think it is safe to assume that most readers are to some degree familiar with Latour's previous work, broadly known as Actor-Network Theory. In

${ }^{3}$ For a recent account of applications of complex systems theory in the field of language studies in Brazil, see Paiva and Nascimento (2011). 
fact, I myself have tried to contribute to a better understanding of ANT in the Brazilian applied linguistics community in the past (BUZATO, 2009,2012a, 2012b, 2013). Therefore, I will focus here on Latour's more recent work, the research project and book entitled "An Inquiry Into Modes of Existence" (LATOUR, 2013, henceforth AIME).

The notion of modes of existence is related to the concept of category in metaphysics. Categories represent general kinds that govern our conceptual schemes of the real. Each mode of existence is characterized by five agentive (rather than substantive) properties: the discontinuities it seeks to bridge, the kinds of action it bridges such discontinuities with, the necessary conditions for the bridging to hold, the kind of beings such continuities institute, and what kinds of beings-as-otherness (alterations) these beings are subjected to.

Technology (referred to as [TEC] in AIME), is the mode which sets up associations of agencies to overcome resistances of the other modes. The beings of technology are "delegates" who perform actions on behalf of other beings, silently and relentlessly, anticipating/defeating/excluding uncertainties. ICTs (as technical infrastructure) can be described as a crossing of [TEC] and Double-Click (referred to as [DC], in AIME). [DC] is the mode of "free, indisputable, and immediate access to pure, untransformed information" (p. 93). Cultural human meanings, on the other hand, are called Reference (or [REF]) in AIME, and it is when [REF] and [DC] cross that disputed aboutness, as I have called it, shows. Every cyborg meaning has a potential ethical worth that is unable to be manifested as a being of [DC]. I can block a social network user who sends me pictures of naked children or I can add such a user, but, in both cases, [DC] is simply adding or subtracting the pertinent user ID from the vector that represents who I am as a function of the unique combination of users I have marked as "friends." Yet was the act about friendship or crime? Pornography or affinity? I could be a pediatric dermatologist or a pedophile, how is [DC] supposed to know? Yet [DC] and $[\mathrm{REF}]$ are involved in either medicine or crime.

When one mode passes through another, they entertain a means-end relation, and that relation is what constitutes ethics ([MOR] ality in AIME) as a mode of existence. Using the two theories in the same apparatus should allow us to pursue both the environmental effects of the passing of material reference - what computer-human peers do together experientially in the physical world in their situated sociocultural activities - through [TEC]. 
[DC], and the new material-semiotic possibilities that become available in situated sociocultural practices where humans and computers peer up - how the beings sustained by [TEC][DC] materialize in the thread of humancomputer experiences.

For Latour (2013, p. 455), "if every existent remakes the world in its own way and according to its own viewpoint, its supreme value is of course that of existing on its own" (p. 455). This, of course, reminds us of Floridi's (2010) attempt at an ontocentric applied ethics, but in Latour's version, it is not about letting everything be: it's about how each being negotiates its means or ends identity in relation to each other. For Latour (2013, p. 461), ethics as a mode of existence has no limits, since "everything in the world evaluates". For Lemke (2015), there is an intrinsic evaluative dimension to every material-semiotic act, every meaning and feeling process. Could we, perhaps, research ways for [DC] to capture human feelings about the way [DC] itself works in different human-computer encounters? Should we not start worrying seriously about how the [DC] that captures human feelings through biometric technologies is and will be used to tailor cyborg experiences?

The way AIME qualifies morality speaks directly to reflexivity in each disciplinary field and in the interdisciplinary endeavors of the kind I am advocating here. A democratic, interdisciplinary, environmentally-oriented effort on applied ICT ethics should be open, continuous, and holistic. Hence the utility of an ambi-optic apparatus

\section{In conclusion: questions towards a different beginning}

I will now return to my anecdote and suggest some examples of purposefully broad and vague research questions for interdisciplinary teams pursuing a posthumanist/postsocial ethics of here and now.

First of all, what people in such teams should ask and answer for themselves and to others, in a language that is as "ordinary" as possible, and not necessarily using AIME's notation and vocabulary, is what modes of existence prevail in their fields and how the modes involved in a given ethical issue relate among themselves in terms of means and ends. This will inevitably lead to the political dimension of the issue, and require a democratic way of making interdisciplinary politics. The key to a successful political agreement that may call itself democratic is that users, and not the disciplines of the practitioners, are effectively taken as the end and not used as the means. 
In our anecdote, this kind of talk could have led to research into biometric identification techniques and letting the computer deal with numbers, possibly retrieving information from different governmental databases where those are already available instead of using the citizen as a repository of numbers from one agency that other agencies can consult. It could also have meant researching adaptive interfaces that learned from local people's languaging while informing local educational agents of what literacies should be taught at school more often and by what means, as well as, among other possibilities, the opportunity to find out how many functionally illiterate people there were in each community, what kinds of literacies were most necessary, and the providing of this information to local education practitioners, for example.

Finally, a second set of questions inspired in ES should help us see the kind of "environmental moral effects" there are when we look at a community of cyborg citizens, as human-computer peers' semiotic activity unfolds in time and space across scales. For example, a citizen seeking a medical appointment feels "something going on" with cells and chemicals in her body that she can only experience as "symptoms." A doctor can tell what is behind the symptoms through the mediation of "medical inscriptions" that depend, in turn, on computer activity. For the hospital to be paid by the government, there must be a "documented case", which means it must pass through a computer, with templates and forms that a clerk, or a patient, or both, fill out. Inside all of these computers, there are cybernetic agents doing very fast things, unnoticed by users, except when they go wrong, in which case they are perceived as defects or bugs. It takes a doctor to allow people's symptoms to pass through the mode of existence of an "official" disease. It takes a computer technician to let the failure of cybernetic agents inside the computer become bugs. It takes many other mediations for a biographical subject to become a doctor or a computer technician. But the disease only exists in the mode that governmental bureaucracy recognizes if there is no interruption in the trajectory from symptom to payment, from person to doctor or technician, and so forth. Is it fair to consider that the disease stopped if the software agent stopped or the process of training or paying a doctor or a technician for the community stops? If not, what alterations should be available for the disease to be treated as such? How many degrees in fever correspond to so many minutes waiting for a computer to reboot, an overworked doctor to open the door, a technician to fix a bug? How often 
does it happen in the community that hospitals get paid for diseases that were not there and that patients get worse because a non-human agent was not there when necessary? Would it cost less financially and politically to bring more human attendants to the community more often or to improve literacy education in the community or to deploy a better computer infrastructure locally?

These are, obviously, not the only, and possibly not the best, questions the apparatus could suggest, but they suffice to illustrate the relevance of pursuing such an idea. As put forth in the whole of this essay, I ask the reader to look at these elements as an invitation to imagine our ethical future by looking at what we are becoming with computers in the here and now.

\section{Acknowledgement}

This research was sponsored through grant 2014/25315-7, São Paulo Research Foundation (FAPESP)

\section{References}

ALEXANDER, Larry; MOORE, Michael. Deontological Ethics. In: ZALTA, EDWARD N. (Org.). The Stanford Encyclopedia of Philosophy. Spring 2015 ed. [S.l: s.n.], 2015. Available at: <http://plato.stanford.edu/archives/spr2015/entries/ ethics-deontological/>. Accessed on: March 5, 2016.

BENTHAM, J.; BURNS, J. H.; HART, H. L. A. A fragment on government. New authoritative edition. Cambridge; New York: Cambridge University Press, 1988. BLACKBURN, Simon. Being good: a short introduction to ethics. Oxford: Oxford Univ. Press, 2002.

BRANDT, R. B. Moral Philosophy and the Analysis of Language. Lawrence: The University of Kansas, 1963, [S.1: s.n.], 1963.

BUECHNER, J. Trust and Ecological Rationality in a Computing Context. SIGCAS Comput. Soc., Milwaukee, WI, v. 43, n. 1, p. 47-68, May 2013. Available at: <http://doi.acm.org/10.1145/2505414.2505419>. Accessed on: Sep 13, 2015

BUNGE, M. Method, Model and Matter. Dordrecht: Springer Netherlands, 1973. Available at: <http://dx.doi.org/10.1007/978-94-010-2519-5>. Accessed on: December 7, 2015.

BUZATO, Marcelo E. K. Letramento, novas tecnologias e a Teoria Ator-Rede: um convite à pesquisa. Remate de Males, Campinas, v. 29, n. 1, p. 71-87, 2009. 
BUZATO, Marcelo El Khouri. Letramentos em rede: textos, máquinas, sujeitos e saberes em translação. Revista Brasileira de Linguística Aplicada, Belo Horizonte, v. 12, n. 4, p. 783-809, 2012a.

BUZATO, Marcelo El Khouri. Práticas de letramento na ótica da Teoria Ator-Rede: casos comparados. Calidoscópio, São Leopoldo, v. 10, n. 1, p. 65-82, 2012 b.

BUZATO, Marcelo El Khouri. Mapping Flows of Agency in New Literacies: Self and Social Structure in a Post-social World. In: JUNQUEIRA, Eduardo S.; BUZATO, Marcelo E. K. (Orgs.). New Literacies, New Agencies: a Brazilian perspective. New York: Peter Lang, 2013. (New Literacies and Digital Epistemologies).

BYNUM, T. Computer and Information Ethics. In: ZALTA, E. N. (Org.). The Stanford Encyclopedia of Philosophy. Winter 2014 ed. [S.l: s.n.], 2014. . Available at: <http://plato.stanford.edu/archives/win2014/entries/ ethics-computer/>. Accessed on: September 4, 2015.

BYNUM, T. Norbert Wiener's Vision: the Impact of the "Automatic Age" on our Moral Lives. In: CAVALIER, R. J. (Org.). The impact of the Internet on our moral lives. Albany: State University of New York Press, 2005. p. 11-25. FLORIDI, Luciano. Distributed Morality in an Information Society. Science and Engineering Ethics, Dordrecht, v. 19, n. 3, p. 727-743, 2013.

FLORIDI, Luciano. Ethics after the Information Revolution. In: FLORIDI, L. (Org.). The Cambridge Handbook of Information and Computer Ethics. Cambridge: Cambridge University Press, 2010. p. 3-19.

FLORIDI, Luciano. Foundations of Information Ethics. In: HIMMA, K. E.; TAVANI, HERMAN T. (Org.). The handbook of information and computer ethics. Hoboken: Wiley, 2008. p. 3-24.

FLORIDI, Luciano. Philosophical conceptions of information. In: SOMMARUGA, G. (Org.). Formal theories of information: from shannon to semantic information theory and general concepts of information. Lecture notes in computer science. 1st ed. Berlin; New York: Springer, 2009. p. 13-53.

FLORIDI, Luciano. What is the Philosophy of Information? Metaphilosophy, Malden, v. 33, n. 1\&2, p. 123-145, January 2002.

GRANT, S. et al. Generalized Utilitarianism and Harsanyi's Impartial Observer Theorem. Econometrica, Malden v. 78, n. 6, p. 1939-1971, 2010. GRAY, C. H. (Org.). The cyborg handbook. New York: Routledge, 1995. GRAY, C. H. Cyborg citizen: politics in the posthuman age. New York: Routledge, 2000. 
HALLIDAY, M. A. K. Language as social semiotic: the social interpretation of language and meaning. Baltimore: University Park Press, 1978.

HANSEN, J. The Paradoxes of Deontic Logic: Alive and Kicking. Theoria, Malden, v. 72, n. 3, p. 221-232, 11 fev. 2008.

HAYLES, K. How we became posthuman: virtual bodies in cybernetics, literature, and informatics. Chicago: University of Chicago Press, 1999.

HAYLES, N. K. Unfinished Work: From Cyborg to Cognisphere. Theory, Culture \& Society, Goldsmiths, v. 23, n. 7-8, p. 159-166, Dec. 1. 2006.

HAYLES, N. K.. Wrestling with transhumanism. In: GRASSIE, W.; HANSELL, G. R. (Org.). H+/-: Transhumanism and Its critics. Philadelphia: Metanexus Institute, 2011. p. 215-226.

HEIDEGGER, M. Being and time. London: SCM Press, 1962.

HEIDEGGER, M. Poetry, language, thought. New York: Harper \& Row, 1971. HURSTHOUSE, R. Virtue Ethics. In: ZALTA, E. N. (Org.). The Stanford Encyclopedia of Philosophy. Fall 2013 ed. [S.l: s.n.], 2013. Available at: <http:// plato.stanford.edu/archives/fall2013/entries/ethics-virtue/>. Accessed on: September 4, 2015.

IHDE, D. Of which human are we post? In: GRASSIE, W.; HANSELL, G. R. (Org.). H+/-: Transhumanism and Its critics. Philadelphia: Metanexus Institute, 2011.p. 136-146.

INTRONA, Lucas D. On the ethics of (object) things. Lancaster: Lancaster University 2003. Available at: <http://eprints.lancs.ac.uk/48689/>. Accessed on: November 28, 2015.

INTRONA, L. D. Towards a Post-human Intra-actional Account of Sociomaterial Agency (and Morality). In: KROES, P.; VERBEEK, P. P. The Moral Status of Technical Artifacts. Dordrecht: Springer, 2014. p. 31-53. JOHNSON, D. G. Computer ethics. 1. ed. Englewood Cliffs: Prentice Hall, 1985.

JOHNSON, D. G. Computer systems: Moral entities but not moral agents. Ethics and Information Technology, Dordrecht, v. 8, n. 4, p. 195-204, November 1, 2006.

JOYCE, Richard. Moral Anti-Realism. In: ZALTA, E. N. (Org.). The Stanford Encyclopedia of Philosophy. Summer 2015 ed. [S.l: s.n.], 2015. Available at: <http://plato.stanford.edu/archives/sum2015/entries/moralanti-realism/>. Accessed on: September 15, 2015. 
KING, P. Abelard's Intentionalist Ethics. The Modern Schoolman, Charlottesville, v. 72, n. 2, p. 213-231, 1995.

KNORR-CETINA, K. Sociality with Objects: Social Relations in Postsocial Knowledge Societies. Theory, Culture \& Society, Goldsmiths, v. 14, n. 4, p. 1-30, November 1, 1997.

KNORR-CETINA, K.. Post-social Relations: Theorizing Sociality in a Post-social Environment. In: RITZER, George; SMART, Barry (Org.). Handbook of Social Theory. London: Sage Publications, 2001. p. 521-535.

KNORR-CETINA, K. Postsocial. In: RITZER, G. (Org.). Encyclopedia of social theory. Thousand Oaks: Sage, 2005. v. 2. p. 585-590.

KRAUT, R.. Aristotle's Ethics. In: ZALTA, E. N. (Org.). The Stanford Encyclopedia of Philosophy. Summer 2014 ed. [S.l: s.n.], 2014. . Available at: <http://plato. stanford.edu/archives/sum2014/entries/aristotle-ethics/>. Accessed on: Aug 18, 2015.

LATOUR, B.; VENN, C. Morality and Technology: The End of the Means. Theory, Culture \& Society, Goldsmiths v. 19, n. 5-6, p. 247-260, December $1,2002$.

LATOUR, Bruno. On actor-network theory: A few clarifications plus more than a few complications. Soziale Welt, v. 47, n.4, p. 369-381, 1996.

LATOUR, B. How to Talk About the Body? the Normative Dimension of Science Studies. Body \& -Society, Goldsmiths,v. 10, n. 2-3, p. 205-229, June $1,2004$.

LATOUR, Bruno. An inquiry into modes of existence: an anthropology of the moderns. Cambridge: Harvard University Press, 2013.

LEMKE, J. L. Textual politics: discourse and social dynamics. London; Bristol: Taylor \& Francis, 1995.

LEMKE, J. L. Across the Scales of Time: Artifacts, Activities, and Meanings in Ecosocial Systems. Mind, Culture, and Activity, San Diego, v. 7, n. 4, p. 273-290, 2000.

LEMKE, J. L. Discursive Technologies and the Social Organization of Meaning. Folia Linguistica, Leuven, v. 35, n. 1-2, p. 79-97, 2001.

LEMKE, J. L. Travels in hypermodality. Visual Communication, Thousand Oaks, v. 1, n. 3, p. 299-325, 2002a. 
LEMKE, J. Language development and identity: Multiple timescales in the social ecology of learning, In: KRAMSCH, Claire J. (Org.). Language acquisition and language socialization: ecological perspectives.. London, New York: Continuum, p. 68-87, 2002b.

LEMKE, J. L. Mathematics in the middle: Measure, picture, gesture, sign and word. In: ANDERSON, M. (Org.). Educational perspectives on mathematics as semiosis: from thinking to interpreting to knowing. New directions in the teaching of mathematics. Brooklyn: Legas, 2003. p. 215-234.

LEMKE, J. Multimodal genres and transmedia traversals: Social semiotics and the political economy of the sign. Semiotica, Berlin, v. 1/4, n. 173, p. 283-297, January 2009.

LEMKE, J. L. Feeling and Meaning: A Unitary Bio-semiotic Account. In: TRIFONAS, P. P. (Org.). International handbook of semiotics. Dordrecht: Springer Dordrecht, 2015. p. 589-616.

LENMAN, J. Moral Naturalism. In: ZALTA, E. N. (Org.). The Stanford Encyclopedia of Philosophy. Spring 2014 ed. [S.l: s.n.], 2014. Available at: <http:// plato.stanford.edu/archives/spr2014/entries/naturalism-moral/>. Accessed on: September 15, 2015.

MANER, W. Starter Kit in Computer Ethics. Hyde Park: Helvetia Press and the National Information and Resource Center for Teaching Philosophy, 1980.

MANER, W. Unique Ethical Problems in Information Technology. Science and Engineering Ethics, Dordrecht, v. 2, n. 2, pp. 137-154, 1996.

MCGRAIL, R. Working with Substance: Actor-Network Theory and the Modal Weight of the Material. Techné: Research in Philosophy and Technology, Techne, v. 12, n. 1, p. 65-84, 2008.

MOOR, J. H. Reason, Relativity, and Responsibility in Computer Ethics. In: SPINELLO, R. A.; TAVANI, H. T. (Org.). Readings in cyberethics. 2nd ed. Sudbury: Jones and Bartlett Publishers, 2004. p. 21-38.

MOOR, J. H. What Is Computer Ethics? In: BYNUM, T. (Org.). Computers and Ethics. Malden: Blackwell, 1985. p. 266-275.

PAIVA, V. L. M. O. ; NASCIMENTO, M. (Org.). Sistemas Adaptativos Complexo: lingua(gem) e aprendizagem. Campinas: Pontes, 2011.

RIDGE, M.. Moral Non-Naturalism. In: ZALTA, E. N. (Org.). The Stanford Encyclopedia of Philosophy. Fall 2014 ed. [S.l: s.n.], 2014 . . Available at: <http:// plato.stanford.edu/archives/fall2014/entries/moral-non-naturalism/>. Accessed on: September 15, 2015. 
SALTHE, S. N. A Hierarchical Framework for Levels of Reality: Understanding Through Representation. Axiomathes, Dordrecht, v. 19, n. 1, p. 87-99, March 2009.

SALTHE, S. N.; SALTHE, B. M. Ecosystem Moral Considerability: A Reply to Cahen. Environmental Ethics, Denton, v. 11, n. 4, p. 355-361, 1989.

SPINELLO, R. A.; TAVANI, H. T. (Org.). Readings in cyberethics. 2nd ed. Sudbury: Jones and Bartlett Publishers, 2004.

STREET, B. V. Literacy in theory and practice. Cambridge [Cambridgeshire]; New York: Cambridge University Press, 1984.

THIBAULT, P. J. First-Order Languaging Dynamics and Second-Order Language: The Distributed Language View. Ecological Psychology, Hartford, v. 23, n. 3, p. 210-245, 2011.

VAN LEEUWEN, T. Introducing social semiotics. London; New York: Routledge, 2005.

VAN ROOJEN, M. Moral Cognitivism vs. Non-Cognitivism. In: ZALTA, E. N. (Org.). The Stanford Encyclopedia of Philosophy. Fall 2015 ed. [S.1: s.n.], 2015. Available at: <http://plato.stanford.edu/archives/fall2015/ entries/moral-cognitivism/>. Accessed on: October 8, 2015.

WIENER, N. The human use of human beings: cybernetics and society. New York: Da Capo Press, 1954.

WOLF, A. Giving up Hume's Guillotine. Australasian Journal of Philosophy, Hobart, v. 93, n. 1, p. 109-125, January 2, 2015.

Data de submissão: 10/03/2016. Data de aprovação: 10/06/2016. 